\title{
Hubungan Pemberian ASI Eksklusif dan Lingkar Kepala dengan Perkembangan Motorik Bayi Usia 6-12 Bulan di Surakarta
}

\author{
Siwi Hesti Utami ${ }^{1}$, Budiyanti Wiboworini ${ }^{2}$, Eti Poncorini Pamungkasari ${ }^{3}$ \\ 1. Program Studi Kedokteran Fakultas Kedokteran, Universitas Sebelas Maret \\ 2. Bagian Ilmu Gizi Fakultas Kedokteran, Universitas Sebelas Maret \\ 3. Bagian Ilmu Kesehatan Masyarakat Fakultas Kedokteran, Universitas Sebelas Maret
}

Korespondensi : siwihestiutami@student.uns.ac.id

\begin{abstract}
ABSTRAK
Pendahuluan: Perkembangan motorik perlu diperhatikan untuk mendeteksi ada tidaknya keterlambatan dalam perkembangan bayi yang dapat berpengaruh terhadap potensinya di masa mendatang. Perkembangan motorik dipengaruhi oleh beberapa faktor, diantaranya yaitu pemberian ASI eksklusif dan lingkar kepala. Laktosa, taurin, asam dokosaheksaenoat, dan asam arakidonat yang banyak terdapat dalam ASI berperan penting dalam perkembangan motorik bayi. Lingkar kepala berkaitan dengan perkembangan otak yang merupakan salah satu organ pengendali motorik. Penelitian ini bertujuan untuk mengetahui hubungan pemberian ASI eksklusif dan lingkar kepala dengan perkembangan motorik bayi usia 6-12 bulan di Surakarta.

Metode: Penelitian ini merupakan penelitian analitik observasional dengan desain studi cross sectional. Subjek penelitian adalah bayi berusia 6-12 bulan di Wilayah Puskesmas Gajahan dan Puskesmas Ngoresan Surakarta yang memenuhi kriteria inklusi. Penelitian dilakukan dengan wawancara, pengukuran lingkar kepala, dan penilaian perkembangan motorik. Sampel penelitian berjumlah 84 yang dipilih menggunakan teknik purposive sampling.

Hasil: Terdapat hubungan yang positif dan signifikan antara pemberian ASI eksklusif $(\mathrm{p}<0,001 ; \mathrm{OR}=9,88)$ dengan perkembangan motorik bayi usia $6-12$ bulan. Tidak didapatkan hubungan yang signifikan antara lingkar kepala $(\mathrm{p}=0,208 ; \mathrm{OR}=5,35)$, pemberian MPASI $(\mathrm{p}=0,242 ; \mathrm{OR}=0,52)$, jenis kelamin $(\mathrm{p}=0,400 ; \mathrm{OR}=1,59)$, dan usia $(\mathrm{p}=0,432 ; \mathrm{OR}=0,65)$ dengan perkembangan motorik bayi usia 6-12 bulan.

Kesimpulan: Bayi berusia 6-12 bulan yang diberi ASI eksklusif dan memiliki ukuran lingkar kepala normal berpeluang lebih besar untuk mengalami perkembangan motorik sesuai umur.
\end{abstract}

Kata Kunci: ASI eksklusif, lingkar kepala, perkembangan motorik bayi.

\begin{abstract}
Introduction: Motor development needs to be considered to detect the presence or absence of delays in infant's development which can affect their potency in the future. Exclusive breastfeeding contains lactose, taurine, DHA, and AA which are needed for motor development. Head circumference is related to brain development as one of motor control organs. This study aimed to analyze the relationship between exclusive breastfeeding and head circumference with motor development of infants aged 6-12 months in Surakarta.

Methods: This was an analytical observational study with a cross sectional design. The subject were infants aged 6-12 months in Puskesmas Gajahan and Puskesmas Ngoresan Surakarta who met the inclusion criteria. Data obtained from interviews, measurements
\end{abstract}


of head circumference, and assessments of motor development, in 84 subjects that selected purposely. The data were analyzed using Chi Square test, Odds Ratio (OR), and logistic regression.

Results: There was a significant relationship between exclusive breastfeeding and motor development ( $p<0,001 ;$ OR $=9,88)$ but no significant relationship was found between head circumference and motor development $(p=0,208 ; O R=5,35)$, complementary feeding and motor development $(p=0,242 ; O R=0,52)$, sex and motor development $(p=0,400$; $O R=1,59)$, age and motor development ( $p=0,432 ; O R=0,65)$.

Conclusion: Infants aged 6-12 months who are exclusive breastfed and had normal head circumference have greater chances to experience motor development that is age appropriate.

Keywords: exclusive breastfeeding, head circumference, infants' motor development

\section{PENDAHULUAN}

Perkembangan motorik adalah bertambahnya struktur dan fungsi tubuh yang merupakan hasil interaksi susunan saraf pusat dengan otot rangka yang dipengaruhinya ${ }^{1}$. Perkembangan motorik terdiri dari motorik kasar dan motorik halus. Motorik kasar berhubungan dengan pergerakan dan sikap tubuh yang melibatkan otot-otot besar, seperti menegakkan kepala, duduk, dan berdiri. Motorik halus memerlukan koordinasi yang cermat dan melibatkan otot-otot kecil, seperti menggenggam dan menggerapai ${ }^{2,3,4}$.

Perkembangan motorik mengontrol gerakan tubuh melalui koordinasi antara otak, saraf tepi, dan otot rangka. Pada tahun pertama kelahiran, perkembangan otak bayi mudah dipengaruhi oleh faktor lingkungan, salah satunya yaitu nutrisi setelah lahir ${ }^{4}$. Pemberian ASI dapat mempengaruhi perkembangan motorik bayi, karena ASI merupakan sumber nutrisi utama bayi ${ }^{2}$. Laktosa, taurin, DHA, dan AA yang banyak terdapat pada ASI berperan penting dalam perkembangan motorik bayi ${ }^{5,6,7}$. UNICEF dan WHO merekomendasikan pemberian ASI secara eksklusif, yaitu pemberian ASI tanpa tambahan makanan atau minuman lain kecuali vitamin, mineral, dan obat dalam bentuk oralit, sirup, atau tetes sejak bayi lahir sampai berusia 6 bulan $^{8,9}$. Pemberian ASI secara eksklusif selama 6 bulan sudah dapat mencukupi kebutuhan nutrisi bayi untuk mencapai perkembangan motorik yang optimal, selanjutnya bayi dapat diberi ASI dengan tambahan makanan pendamping ASI sampai bayi berusia 2 tahun. Pemberian MPASI yang terlalu dini justru dapat menyebabkan bayi memperoleh lebih sedikit ASI sehingga daya tahan tubuhnya menjadi rendah dan perkembangan motoriknya dapat terhambat ${ }^{10}$.

Perkembangan otak berhubungan dengan perkembangan motorik bayi. Perkembangan otak biasanya diikuti dengan pertumbuhan tulang kepala yang dapat diukur melalui pengukuran lingkar kepala ${ }^{11}$. Sejak bayi lahir sampai berusia 1 tahun, penambahan ukuran lingkar kepala terjadi sangat pesat dan rawan, jika terjadi gangguan atau hambatan pada masa itu dapat mengakibatkan gangguan perkembangan motorik yang tidak dapat terkejar pada masa perkembangan selanjutnya ${ }^{12}$. Berdasarkan data dan teori yang ada, peneliti tertarik untuk mengetahui hubungan antara pemberian ASI eksklusif dan lingkar kepala dengan perkembangan motorik bayi usia 6-12 bulan di Surakarta.

\section{METODE}

Penelitian ini merupakan penelitian analitik observasional dengan desain studi cross sectional. Penelitian dilakukan di 
wilayah kerja Puskesmas Gajahan dan Puskesmas Ngoresan pada bulan Oktober dan November 2018. Pemilihan lokasi berdasarkan penelitian sebelumnya yang dilakukan di Kecamatan Pasar Kliwon dan Banjarsari Kota Surakarta bahwa terdapat $44 \%$ balita usia $12-59$ bulan yang mengalami gangguan perkembangan dan $23,1 \%$ balita dengan status gizi tidak normal yang mengalami gangguan perkembangan motorik kasar $^{13,14}$. Subjek adalah bayi berusia 6-12 bulan di wilayah kerja Puskesmas Gajahan dan Puskesmas Ngoresan yang memenuhi kriteria inklusi serta tidak masuk kriteria eksklusi yang ditentukan dalam penelitian. Peneliti memilih bayi berusia 6-12 bulan karena perkembangan saraf dapat dinilai setelah bayi berusia 6 bulan, selain itu penambahan ukuran lingkar kepala dan perkembangan motorik pada masa itu sangat pesat dan rawan ${ }^{15}$. Peneliti juga mempertimbangkan bayi yang sudah bisa mendapatkan ASI secara eksklusif selama 6 bulan karena pentingnya pemberian ASI eksklusif untuk mencegah perkembangan motorik yang terganggu.

Sebanyak 84 subjek dipilih secara purposive sampling dan dihitung berdasarkan rumus Lemeshow. Pengambilan data dilakukan dengan melakukan wawancara terhadap ibu dari responden, pengukuran lingkar kepala bayi, dan penilaian perkembangan motorik menggunakan KPSP. Data yang diperoleh kemudian dianalisis dengan uji regresi logistik untuk mengetahui pengaruh pemberian ASI eksklusif, lingkar kepala, usia, jenis kelamin, dan pemberian MPASI dengan perkembangan motorik bayi.

\section{HASIL}

Sebaran karakteristik subjek penelitian yang didapatkan dapat dilihat pada Tabel 1.
Tabel 1. Karakteristik Subjek Penelitian

\begin{tabular}{lcc}
\hline \multicolumn{1}{c}{ Variabel } & n & \% \\
\hline Usia & & \\
$\quad$ 6-9 bulan & 51 & 60,7 \\
$\quad \geq 10-12$ bulan & 33 & 39,3 \\
Jenis Kelamin & & \\
$\quad$ Laki-laki & 40 & 47,6 \\
$\quad$ Perempuan & 44 & 52,4 \\
Pemberian ASI & & \\
$\quad$ ASI eksklusif & 42 & 50,0 \\
$\quad$ ASI non eksklusif & 42 & 50,0 \\
Pemberian MPASI & & \\
$\quad$ Sesuai & 35 & 41,7 \\
$\quad$ Kurang sesuai & 49 & 58,3 \\
Lingkar Kepala & & \\
$\quad$ Normal & 80 & 95,2 \\
$\quad$ Tidak normal & 4 & 4,8 \\
Perkembangan Motorik & & \\
$\quad$ Sesuai & 56 & 66,7 \\
$\quad$ Terganggu & 28 & 33,3 \\
\hline
\end{tabular}

Tabel 1 menjelaskan bahwa proporsi subjek penelitian lebih banyak berusia 6-9 bulan. Proporsi jumlah subjek laki-laki dan perempuan hampir sama, sedangkan proporsi bayi yang diberi ASI eksklusif sama dengan proporsi bayi yang tidak diberi ASI eksklusif. Hasil penelitian menunjukkan bahwa bayi yang diberi MPASI sesuai lebih sedikit dibandingkan bayi yang diberi MPASI kurang sesuai. Subjek penelitian yang diukur lingkar kepala dan perkembangan motoriknya sebagian besar memiliki ukuran lingkar kepala normal dan perkembangan motorik yang sesuai.

Tabel 2 menjelaskan faktor-faktor yang mempengaruhi perkembangan motorik bayi usia 6-12 bulan. Terdapat hubungan negatif dan tidak signifikan secara statistik antara usia dengan perkembangan motorik bayi $(\mathrm{p}=0,432$; $\mathrm{OR}=0,65$; CI 95\%=0,22-1,90). Bayi berusia $\geq 10-12$ bulan berpeluang mengalami perkembangan motorik yang sesuai $0,7 \mathrm{kali}$ lebih kecil daripada bayi berusia 6-9 bulan. 
Tabel 2. Hasil Analisis Regresi Logistik antara Usia, Jenis Kelamin, Pemberian ASI Eksklusif, Pemberian MPASI, dan Lingkar Kepala dengan Perkembangan Motorik

\begin{tabular}{lccc}
\hline \multicolumn{1}{c}{ Variabel } & p & OR & CI 95\% \\
\hline $\begin{array}{l}\text { Usia }(\geq 10- \\
12 \text { bulan) }\end{array}$ & 0,432 & 0,65 & $0,22-1,90$ \\
$\begin{array}{l}\text { Jenis } \\
\begin{array}{l}\text { Kelamin } \\
\text { (perempuan) }\end{array}\end{array}$ & 0,400 & 1,59 & $0,54-4,64$ \\
$\begin{array}{l}\text { Pemberian } \\
\text { ASI } \\
\text { (eksklusif) }\end{array}$ & $<0,001$ & 9,88 & $3,05-31,97$ \\
$\begin{array}{l}\text { Pemberian } \\
\text { MPASI } \\
\text { (sesuai) }\end{array}$ & 0,242 & 0,52 & $0,17-1,56$ \\
$\begin{array}{l}\text { Lingkar } \\
\text { Kepala } \\
\text { (normal) }\end{array}$ & 0,208 & 5,35 & $0,39-72,85$ \\
\hline
\end{tabular}

Bayi berjenis kelamin perempuan berpeluang mengalami perkembangan motorik yang sesuai 1,6 kali lebih besar daripada bayi laki-laki, ada hubungan yang positif namun tidak signifikan secara statistik $(\mathrm{p}=0,400 ; \mathrm{OR}=1,59 ; \mathrm{CI} 95 \%=0,54-4,64)$.

Bayi yang diberi ASI eksklusif berpeluang mengalami perkembangan motorik yang sesuai 9,9 kali lebih besar daripada bayi yang tidak diberi ASI eksklusif, terdapat hubungan yang positif dan signifikan secara statistik $(\mathrm{p}<0,001 ; \quad \mathrm{OR}=9,88 ; \quad$ CI $95 \%=3,05-31,97)$.

Bayi yang diberi MPASI sesuai berpeluang mengalami perkembangan motorik yang sesuai 0,5 kali lebih kecil daripada bayi yang diberi MPASI kurang sesuai, tetapi tidak signifikan secara statistik $(\mathrm{p}=0,242 ; \mathrm{OR}=0,52 ; \mathrm{CI} 95 \%=0,17-1,56)$.

Bayi yang memiliki ukuran lingkar kepala normal berpeluang 5,4 kali lebih besar mengalami perkembangan motorik yang sesuai daripada bayi yang memiliki ukuran lingkar kepala tidak normal, hubungan ini positif namun tidak signifikan secara statistik $(\mathrm{p}=0,208 ; \mathrm{OR}=5,35 ; \mathrm{CI} 95 \%=0,39-72,85)$.

\section{PEMBAHASAN}

Pemberian ASI eksklusif memiliki hubungan yang positif dan signifikan secara statistik dengan perkembangan motorik bayi. Pemberian ASI eksklusif dapat mendukung perkembangan motorik bayi secara optimal karena ASI mengandung berbagai nutrisi yang berperan penting dalam pertumbuhan dan perkembangan otak, diantaranya yaitu laktosa, taurin, AA, dan $\mathrm{DHA}^{5,6,7}$.

Laktosa akan terurai menjadi glukosa yang merupakan sumber energi untuk perkembangan otak dan galaktosa yang esensial untuk perkembangan otak ${ }^{16}$. Taurin ditemukan dalam jumlah yang sangat tinggi di jaringan otak dan memiliki peran penting dalam perkembangan otak ${ }^{17}$. Akumulasi AA pada otak dan otot rangka berperan penting dalam perkembangan struktur lipid otak dan kontaksi otot. Konsentrasi DHA yang paling tinggi pada area pusat motorik dapat mempercepat hantaran sinyal menuju akson sel saraf sehingga gerak motorik tubuh yang dihasilkan dapat berkembang dengan baik 12,18 .

Hasil penelitian yang sama dijelaskan oleh Purwaningsih bahwa bayi yang diberi ASI eksklusif memiliki perkembangan motorik yang lebih baik dibanding bayi yang diberi nutrisi selain ASI $(\mathrm{p}<0,001 ; \mathrm{t}=-8,14)^{19}$. Hasil penelitian yang sama juga dijelaskan oleh Lisa bahwa terdapat hubungan yang signifikan $(p<0,001)$ antara pemberian ASI eksklusif dengan perkembangan motorik kasar balita. Balita yang tidak diberi ASI eksklusif berpeluang 5,6 kali mengalami perkembangan motorik kasar tidak sesuai umur dibandingkan balita yang diberi ASI eksklusif ${ }^{20}$. Penelitian Fitriana juga menjelaskan bahwa riwayat pemberian ASI memiliki hubungan yang signifikan $(p=0,040)$ dengan perkembangan motorik kasar bayi berusia 6-12 bulan ${ }^{21}$.

Hasil analisis terhadap 84 subjek penelitian menunjukkan bahwa proporsi bayi yang diberi ASI eksklusif sebesar 50\% masih 
tergolong cukup rendah. Hal ini dapat disebabkan oleh beberapa faktor, diantaranya adalah ASI tidak keluar atau keluar sedikit, ibu bekerja, dan bayi rewel. Saat bayi rewel, ibu merasa bayinya lapar sehingga diberi nutrisi tambahan selain ASI sebelum usia 6 bulan. Padahal bayi yang rewel kurang tepat untuk dijadikan alasan memulai pemberian MPASI, tanda-tanda bayi sudah siap menerima nutrisi selain ASI, yaitu bayi dapat duduk dengan kepala tegak, serta bayi mulai meraih makanan dan memasukannya ke dalam mulut ${ }^{22}$.

Hasil analisis hubungan lingkar kepala dengan perkembangan motorik bayi tidak signifikan secara statistik. Hasil ini kurang sesuai dengan penelitian yang dilakukan oleh Yustian yang menyatakan bahwa terdapat hubungan yang signifikan $(\mathrm{p}=0,035)$ antara lingkar kepala dengan perkembangan motorik kasar tetapi tidak terdapat hubungan yang signifikan $(\mathrm{p}=0,987)$ antara lingkar kepala dengan perkembangan motorik halus bayi ${ }^{23}$. Hasil penelitian ini juga berbeda dengan penelitian yang dilakukan oleh Sishadi yang menjelaskan adanya hubungan yang signifikan $(\mathrm{p}<0,001)$ antara lingkar kepala dengan perkembangan motorik kasar anak sindrom Down ${ }^{24}$.

Hasil analisis lingkar kepala dengan perkembangan motorik bayi yang tidak signifikan kemungkinan dapat terjadi karena jumlah bayi dengan ukuran lingkar kepala tidak normal terlalu sedikit dan variasi ukurannya tidak jauh berbeda dengan ukuran lingkar kepala bayi normal. Jumlah bayi yang memiliki lingkar kepala tidak normal hanya berjumlah 4 dari total 84 sampel dimana dari keempat bayi tersebut memiliki rerata perbedaan ukuran lingkar kepala 1,3 cm lebih kecil daripada bayi dengan ukuran lingkar kepala normal.

Hasil analisis hubungan antara usia dengan perkembangan motorik bayi didapatkan hubungan yang negatif dan tidak signifikan secara statistik. Bayi berusia $\geq 10$ -
12 bulan berpeluang 0,65 kali lebih kecil mengalami perkembangan motorik yang sesuai dibanding bayi berusia 6-9 bulan. Hasil penelitian Solihin menjelaskan bahwa semakin bertambahnya usia bayi maka perkembangan motoriknya akan semakin meningkat. Tingkat perkembangan motorik kasar bayi akan meningkat sebesar 0,46\% setiap satu bulan ${ }^{25}$. Hasil analisis usia dengan perkembangan motorik bayi yang tidak signifikan kemungkinan dapat terjadi karena rentang usia bayi yang diteliti tidak terlalu jauh sehingga perbedaan perkembangan motorik antar kelompok bayi tidak jauh berbeda.

Hasil analisis hubungan antara jenis kelamin dengan perkembangan motorik bayi didapatkan hubungan yang positif tetapi tidak signifikan secara statistik. Bayi berjenis kelamin perempuan berpeluang 1,6 kali lebih besar mengalami perkembangan motorik yang sesuai dibanding bayi laki-laki. Hasil penelitian Kokstejn menjelaskan bahwa anak perempuan usia 3-4 tahun memiliki keterampilan motorik yang lebih baik daripada anak laki-laki $(\mathrm{p}<0,010)$, tetapi tidak didapatkan perbedaan keterampilan motorik pada usia 5-6 tahun. Data tersebut menjelaskan bahwa anak perempuan umumnya memiliki keterampilan motorik yang lebih baik daripada anak laki-laki pada usia yang lebih muda tetapi perbedaan tersebut tidak ditemukan menjelang usia prasekolah $^{26}$.

Hasil analisis hubungan antara pemberian MPASI dengan perkembangan motorik bayi didapatkan hubungan yang negatif dan tidak signifikan secara statistik. Pemberian MPASI dikelompokkan menjadi kategori sesuai dan kurang sesuai berdasarkan jenis makanan yang diberikan menurut usia bayi, frekuensi pemberian makanan menurut usia bayi, dan porsi makanan yang diberikan menurut usia bayi ${ }^{22}$. Hasil penelitian menjelaskan bahwa bayi yang diberi MPASI kurang sesuai paling banyak disebabkan oleh 
porsi pemberian MPASI yang terlalu sedikit. Kekurangan asupan nutrisi pada bayi dapat mengakibatkan keterlambatan perkembangan motorik bayi ${ }^{27}$. Hasil analisis pemberian MPASI dengan perkembangan motorik bayi yang tidak signifikan kemungkinan dapat terjadi karena terdapat 26 bayi yang diberi MPASI kurang sesuai dan juga tidak diberi ASI eksklusif, padahal, pemberian ASI secara eksklusif memiliki pengaruh dan hubungan yang signifikan dengan perkembangan motorik bayi.

\section{KESIMPULAN}

Bayi berusia 6-12 bulan yang diberi ASI eksklusif dan memiliki ukuran lingkar kepala normal berpeluang lebih besar untuk mengalami perkembangan motorik sesuai umur.

\section{UCAPAN TERIMA KASIH}

Penulis mengucapkan terima kasih kepada Dr. Yulia Lanti Retno Dewi, dr., M.Si. yang telah membantu penulis dalam melaksanakan penelitian ini.

\section{DAFTAR PUSTAKA}

1. Kemenkes RI. Pedoman Pelaksanaan Stimulasi, Deteksi dan Intervensi Dini Tumbuh Kembang Anak di Tingkat Pelayanan Kesehatan Dasar. 2016;

2. Soetjiningsih. Tumbuh Kembang Anak. Jakarta: EGC; 2014

3. IDAI. Air Susu Ibu dan Tumbuh Kembang Anak [Internet]. IDAI. 2013 [dikutip 14 April 2018]. Tersedia pada: http://www.idai.or.id/artikel/klinik/asi/airsusu-ibu-dan-tumbuh-kembang-anak

4. Kemenkes RI. Pelayanan Stimulasi Deteksi Intervensi Dini Tumbuh Kembang Anak [Internet]. Kementrian Kesehatan. 2010 [dikutip 14 April 2018]. Tersedia pada: http://www.depkes.go.id/development/site $/ \mathrm{jkn} /$ index.php?cid=1137\&id=pelayananstimulasi-deteksi-intervensi-dini-tumbuh- kembang-anak.html

5. IDAI. Nilai Nutrisi Air Susu Ibu [Internet]. IDAI. 2013 [dikutip 14 April 2018]. Tersedia pada: http://www.idai.or.id/artikel/klinik/asi/nila i-nutrisi-air-susu-ibu

6. Brenna JT, Carlson SE. Docosahexaenoic Acid and Human Brain Development: Evidence That Adietary Supply is Needed for Optimal Development. J Hum Evol [Internet]. 2014;77:99-106. Tersedia pada:

http://dx.doi.org/10.1016/j.jhevol.2014.02 .017

7. Mendonca MA, Araujo WMC, Borgo LA, Alencar EDR. Lipid Profile of Different Infant Formulas For Infants. PLoS One. 2017;12(6):1-14.

8. UNICEF. From The First Hour of Life. New York; 2016

9. WHO. Indicators for Assessing Infant and Young Child Feeding Practices. Young [Internet]. 2010;2010(November). Tersedia pada: http://scholar.google.com/scholar?hl=en\& btnG=Search\&q=intitle:Indicators+for+as sessing+infant+and+young+child+feeding + practices\#0

10. Pusdatin Kemenkes RI. Situasi dan Analisis ASI Eksklusif. Jakarta; 2014. hal. 1-8.

11. Gunawan G, Fadlyana E, Rusmil K. Hubungan Status Gizi dan Perkembangan Anak Usia 1-2 Tahun. Sari Pediatr [Internet]. 2011;13(2):142-6. Tersedia pada:

http://saripediatri.idai.or.id/pdfile/13-210.pdf

12. Diana FM. Omega 3 dan Kecerdasan Anak. J Kesehat Masy. 2013;7(2):82-8.

13. Rahayu S. Pertumbuhan dan Perkembangan Balita di Posyandu Surakarta. Interes J Ilmu Kesehat. 2014;3(1):88-92.

14. Sari DW, Nur E, Purwanto S. Hubungan Antara Status Gizi Dengan Perkembangan. J Kesehat. 2012;5(19797621):157-64.

15. Martin CR, Ling P-R, Blackburn GL. 
Review of Infant Feeding: Key Features of Breast Milk and Infant Formula. 2016;1-11.

16. Soetjiningsih. ASI Petunjuk untuk Tenaga Kesehatan. Jakarta: EGC; 2012

17. Andreas NJ, Kampmann B, Mehring LeDoare K. Human Breast Milk: A Review on its Composition and Bioactivity. Early Hum Dev [Internet]. 2015;91(11):629-35. Tersedia pada: http://dx.doi.org/10.1016/j.earlhumdev.20 15.08 .013

18. Hadley KB, Ryan AS, Forsyth S, Gautier S, Salem N. The Essentiality of Arachidonic Acid in Infant Development. Nutrients. 2016;8(4).

19. Purwaningsih E, Lestari AP. Perbedaan Perkembangan Motorik Bayi Usia 0-6 Bulan antara yang diberi ASI dengan yang diberi PASI di Desa Glagah Jatinom Klaten. Involusi Kebidanan. 2012;2:6.

20. Lisa UF. Hubungan Pemberian ASI Ekslusif dengan Perkembangan Motorik Kasar Balita di Kelurahan Brontokusuman Kecamatan Mergangsan Yogyakarta. J Ilm STIKES U'Budiyah. 2012;1(2):1-7.

21. Fitriana IR. Hubungan Riwayat Pemberian ASI dan Berat Badan Lahir dengan Perkembangan Motorik Kasar dan Perkembangan Motorik Halus Bayi Usia 6-12 Bulan. J Nutr Coll. 2016;5:1-7.

22. Kemenkes RI. Pedoman Gizi Seimbang. Jakarta: Kemenkes RI; 2014.

23. Yustian A P. Hubungan Lingkar Kepala dengan Perkembangan Motorik Bayi di Kecamatan Ceper Kabupaten Klaten. 24 Maret 2017 [dikutip 7 Mei 2018]; Tersedia pada: https://eprints.uns.ac.id/32311/

24. Sishadi AS. Hubungan Lingkar Kepala dengan Perkembangan Anak Sindrom Down. J Kedokt Diponegoro. 2015;

25. Solihin RDM, Anwar F, Sukandar D. Kaitan antara Status Gizi, Perkembangan Kognitif, dan Perkembangan Motorik pada Anak Usia Prasekolah. Penelit Gizi dan Makanan. 2013;36(1):62-72.

26. Kokstejn J, Musalek M, Tufano JJ. Are sex differences in fundamental motor skills uniform throughout the entire preschool period? 2017;1-10.

27. Timuda CE. Hubungan Status Gizi Anak dengan Perkembangan Motorik Kasar pada Anak Usia Bayi dan Balita (0-59 Bulan) di Puskesmas Pandanwangi Malang. UMM Sci Journals. 2014;11522. 